\title{
Approach of Absolute being. Philosophical, Theological and Psychological viewpoin
}

\author{
MA, DD, PhD. Spyridon K. TsITSIGKos \\ Dr of Theology \& Dr of Psychology \\ Faculty of Orthodox Theology, University of Athens, \\ GREECE, \\ E-mail: stsitsig@yahoo.com
}

\begin{abstract}
In this poly-prismatic short study is examined historically and totally the diachronic attempts of an approach of "Absolute being" from the side of thinking man. More specifically it is searched philosophical and theological doubting and seeking for the existence of "Absolute being," as for the - conscious or unconscious - its influences above in human mentality. Also, it is discussed generally if firstly is feasible any approach of „Absolute being" by man. Moreover, the various philosophicaltheological and religious-psychological ways of approach of „Absolute being" are recorded as also and how this "approach" is meant. Finally, it is reported the theological perpetual process of approach of "Absolute being" as the profound reasons of this ,approach".
\end{abstract}

Keywords: Absolute being; thinking; relation; world; perfection;

\section{Introduction}

The subject "Approach of Absolute being" constitutes an old but at the same time diachronic question so much for Philosophy, what for Theology and Psychology. Of course, some assessments about "Absolute being" require philosophical, theological and psychological concepts and categorems. Today - in the postmodern age - the term "Absolute being" does not well-use because, evidently or sub-conscionably, creeps a global - horizontally and vertically - practical Atheism [that is to say existential indifference, or rather torpor (akedia), for the Transcendental and generally the metaphysical questions], a Relativism, Skepticism and Agnosticism.

Theology, certain, considers God as "Absolute being", and Philosophy as a supreme Value, or (intellectual or existential) a "Foundation" and a Principle, while, finally, Psychology as certain ideal objectives for a healthier existence of modern man, which however objectives change occasionally, under the effect of Philosophy, Culture or even (individual or collective) experience generally. The all under the above-mentioned title subject is admittedly immense and enormous; it generally includes all almost the history of Philosophy and intellect world. For this reason its approach by necessity will only be limited in a large grains description in order to the panorama of occasionally solutions is delineated, that (solutions) has been proposed for the "approach" - from the side of man of this "Absolute being".

Thus, the contribution of this lies mainly on the one hand in single (overall) confrontation of an examination of "Absolute being", something that the older years were not getting used (perhaps because some perseverance in a one-sided or specialized regard) and on the other hand in the collection of certain conclusions, which is accompanied by a 
criticism, from the viewpoint of Orthodox Christian Tradition.

We said already that the under development this subject has occupied humanity from the primeval years. In the present paragraph we shall be mentioned succinctly -for historians and only reasons - in writers with their works, which dealt ad hoc with the same speculation.

In the Old Testament, the prophet Amos (787-747 B.C.) writes: "Seek me that you may live" $(5,4)$. This means, according to the Prophet, that the searching for God-from the side of man - doesn't constitute a luxury or a sideline, but need of life; need of search of meaning and aim of the human life. Then, Saint Gregorius Nyssenus (335-394 A.D.), as the philosophical Father of Church - within a Christian environment- talks and writes extensively for this search of God from the side of man.

Afterward, in the $17^{\text {th }}$ century, the known work Paradise Lost (1667) of Englishman poet John Milton (1608-1674) is presented, inside that we get elements of search of Divinity.

Then, at the $20^{\text {th }}$ century, German-American theologian-philosopher Paul Tillich (18861965) publishes his work My Search for Absolutes (New York: Simon and Schuster, 1967), with an existential tinge, while in 1974 George Steiner (1929-) his work The nostalgia of the Absolute. Similarly, John Lankford writes In Search of God (1997), with apologetic vein.

Lastly, Eric Weiner wrote Man Seeks God - My Flirtations with the Divine (Twelve, New York-Boston, 2011) with a pan-religious attitude.

In Greece, the following relevant works are published: a) the book of Seeking Creator with scientific criteria (Athens 2002) of N. K. Antonopoulos with apologetic orientation, and b) the book Traces in the Search of Transcentedal (Athens 2004) of Orthodox Archbishop of Albania Anastasios Giannoulatos with prism ecumenistic and missionaristic.

Here however it will be observed that (philosophical) expression "Absolute being" does not correspond (and consequently neither it satisfies) in the beliefs of Religions, very more the Orthodox Christian Theology. Because, according to the Orthodox Tradition, human life, self-consciousness and Triune Godhead is not neither (abstract) philosophically Absolute, neither a (created) being.

With all these, we are compelled - in the context of a philosophical-theological perspective - to analyze briefly: a) possibility utterance - from the finite man - about an absolute being, b) the meanings and the prehensions of being, c) the possibility of somebody elementary definition what we call Absolute, d) the arguments and the reasons of existence or not of the Absolute generally, as well as of its substantive way, e) whether is feasible or no any approach of "Absolute being" from the created and finite man, f) the causes or reasons of approach - from the side of man - of "Absolute being" and g) how various occasionally philosophers saw Absolute, even if -and this equally apply to so much for the theologians what for psychologists - they do not name it thus.

Next, a theological viewpoint generally of Absolute ordains the brevity at least unproductive recording: a) of Affirmative and Negative ways of uttering of Theology, and b) of the event basically of perpetual approach - from the side of man - of "Absolute being" (that is to say God). Moreover, as for the psychological perspective of an approach of "Absolute being" we expose the thereupon opinions of various psychological Schools. In the last Chapter ("Meanings of the approach of the Absolute being") we describe - such from the viewpoint of Philosophy and Religions, as the Religious-psychology - practical and experiential ways of approach of the "Absolute being". 


\section{Prolegomena in the approach of "Absolute being". The possibility of utterance for being absolute}

Because Absolute constitutes a by definition transcendental concept of the man, we were called, firstly, to answer the question if we can speak for "being" Absolute. On this, philosophized thought, intelligentsia and language answer:

a) We know nothing for Absolute (Agnosticism),

b) We cannot, or we can speak for this (Dogmatism, Pyrrhonism, Relativism), and

c) We can speak, but under conditions (like Criticism of I. Kant and Religions).

In the case of Kant we have the segregation between "phenomena", that we can approach, and 'thing by itself', that we cannot approach it[1].

Moreover, in the case of Religions, we can approach the "Absolute being" (that for them, of course, is considered Divinity or Sacred or Holy), but under certain presuppositions, that vary in each Religion.

Accordingly, man, even if relative and finite, holds resources and ways - even faulty in order to express itself (doxologically, negatively etc.) about "Absolute". Orthodox Patristic Theology rescues as girl of eye this balance between Reason and Silence for "Absolute" (i.e. God).

\section{Meanings and apprehensions of "being"}

Under the term "being" Philosophy means usually:

a) "God" (if it is one affirmative or even negative Onto-theology, which identifies indiscriminately substance and existence). Similarly, a theistic Philosophic-theology can mean again God, but with the concept of no identification, but union or participation a substance (Logos) and existence (thing). This last one accepts as Judaism (cf. Davar) as Christianity (cf. G. Athanasius and Eastern Fathers of Church).

b) "Beyond of substance" (Plato), i.e. the "thereinafter of being": this, for Plato, was Good, for Plotinus, One, while for the Irish theologian-philosopher Johannes Scotus Eriugena (815-877) and the German mathematician and philosopher Gottfried Wilhelm Leibniz (1646-1716), God.

c) "Substance" (cf. Essentialism), that is to say 1) the (pure) "esse" (cf. Onto-theology of Thomas Aquinas and Paul Tillich), 2) the substance (Augustine of Hippo, Averroes), 3) Nominalism, 4) Realism and 5) Conceptualism (Peter Abelard).

d) "Energy" (see Energism), that accepted the philosophers Heraclitus of Ephesus (544484 B.C.), Johann Gottlieb Fichte (1762-1814) and Georg Wilhelm Friedrich Hegel (17701831).

e) a dualism (Anaxagoras and Descartes),

f) an identification between "esse" and "conceiving" (Parmenides),

g) a disjunction between being and "esse" (M. Heidegger),

h) a coexistence (N. Malebranche, B. Spinoza, Phenomenology) or synthesis between "thing by itself" or substance or "esse" or "virtually" (Ch. Wolff) or the mind (Berkeley) and existence or form or chance (symvevikos = a non-essential) [Avicenna, Averroes] or "actually" (Aristotle, Th. Aquinas, D. Banez, F. Suarez) or matter (La Mettrie) or being or phenomenon (I. Kant).

i) Existence, according to the Existentialism (S. Kierkegaard, J.-P. Sartre, J. Zizioulas). Nevertheless, if as "being" we consider existence, then de facto this being cannot be something it constant (as a foundation) - unless the existence be "ontologized" (see 
Essentialism) -, therefore we fall in Relativism, vagueness, Discordianism, indeterminateness, uncertainty, tolerance, allowing of everything, pan-freedom (J.-P. Sartre), and, finally, the abolition of each Metaphysics. But, human thought cannot be surpassed thought!

The diversity of philosophical significances of "being" (cf. Ontology) not only hinders the work of Philosophy in - from man - investigation of an approach of "Absolute being", but also causes unimaginable agitations, conflicts and confusions. Judaic-Christian Revelation, removed from anyone (created) "definition" of "Absolute" (viz. God), achieves to exceed the created limits of being.

\section{Determining the Absolute}

Absolute by definition is not defined. If however it is not limited, it is impossible finite man approaches it anyway. For this reason, various occasionally philosophers and theologians attempted to give a sketchy and broad (generally and vaguely) "definition" of the Absolute, so as to they can somehow think it and study. Of course, it is true that the term "Absolute" is related more with Philosophy, while philosophical Theology uses usually the term "Transcendental" or "Uncreated".

Under the term "Absolute" we mean:

a) space-timely, in worthy or intellectually unlimited, infinity and unending (Anaximander),

b) simple, pure, unconditioned (a priori), stand-alone and self-contained / self-sufficient (the "thing by itself"), i.e. roundly uncorrelated (not depended),

c) the cardinal causally source of each being, that is to say entirely unprovoked (uncreated),

d) ultimate authority (as to the knowledge, goodness and true) or supreme force (inflexible and authoritarian),

e) Absolute immoderateness (what however comes contrary to the other definition of the Absolute, that is to say of absolute necessity),

f) absolute wholeness, that is to say "complete" (Aristotle), which however comes again contrary to the other definition of Absolute as "infinity",

g) absolute perfection, which objects similarly in uncoordinated (that is to say absolute liberality),

h) entirely inconceivable (indefinable), and

i) A unique experience, that contains everything by right of corresponding teachings of Hinduism [cf. neo-Hegelian British Idealist Philosopher Francis Bradley (1846-1924)].

All these definitions of "Absolute" confirm its indefiniteness and in-determination. Simultaneously however they testify the human contradictoriness, also the weakness finally of the utterance of a single language (see $\mathrm{Babel}$ ) for the concept and the conception of "Absolute". Orthodox Theology of Pentecost comes to "covers" and exceeds this "lack".

\section{The existence of Absolute}

Any thought, mention and analysis for Absolute will be being certainly utopia, if this said Absolute did not exist actually (objectively). Thus, in question if Absolute exists, Philosophy answers: a) with scepticism (that is to say with doubt), b) with relativism (that is to say with negative answer), and c) with the condition of dialectic existence of its opposite that is to say about the relative (G. Hegel).

This "passive", the agnostic and a circumspect attitude of all Philosophy vis à vis the existence of "Absolute", as it is obvious, facilitates the work "in Christ" of Divine Revelation and (Apologetic) Theology. 


\section{Is it feasible any approach of "Absolute being" from man?}

And here again the answers vary:

a) Agnosticism.

b) absolutely Yes (Materialism, Nihilism, Natural Theology, heretic Eunomius[2]).

c) absolutely No (Scepticism, practical Atheism).

d) Under the (orthodox) conditions:

- no immoderate, extortionate (cf. magic) and psychopathological (neurotic / psychotic) approach (seeking out: blackmail) of God[3].

- integration between discovery ("conceptualizing"/"understanding": word) and revelation (luceo, «be seen»: sight / light or heart) of the way of approach of God: "The surprise that we front feel in biggest is not decreased even if the way with who takes place something from paradoxical is discovered"[4].

- Internal purgation / catharsis (overshooting of selfishness: humbleness).

- Divine aid in the approach of God.

Agnosticism, Skepticism, continuous palinodes and generally the hesitancy, especially of the modern Philosophy, towards the question about the possibility or not approach -from the side of man- of "Absolute being" undermine any "tough" and intolerant, particularly in the past, the attitude of the atheistic and materialistic Philosophy.

\section{Man's causes of the approach of "Absolute being"}

A reasonable question that is caused by the man is why we approach the "absolute being". Thereupon occasionally have been formulated three groups of answers that entwine Philosophy, Theology and Psychology:

a. because of metaphysical or intellectual (religious) needs (A. Maslow), propensities, (unconscious) expectations and sentiments:

- the knowledge of God (Aristotle, Basil the Great, Thomas Aquinas).

- Divine fear (that theological it refers in the said relation of a slave between man and God).

- Ad imaginem et similitudinem Dei. It is theologically an innate impetus to selftransgression (E. Berggrav) or theistic Entelechy (Augustine, K. Rahner). With this prospect entire the life of the faithful is comprehended as pilgrimage (sacred migration), that is to say as a walk, a journey or a continuous spiritual fight to perfection (see fight of Jacob or the monocular German god Wodan / Odin, whose name means furiousness / battle). Archetypal examples in the meaning of traveling or spiritual ascent (see Scale of Jacob) we have Odysseus or Abraham (the father of faith), that travels [5], no however in order to find God, but at the command of God. Similarly stamped in "imago Dei" Divine Logos prompts us no simply - with holy awe and respect - to seek as the Ancient Greeks an "Unknown God", who exceeds us, but -via of faith- to approach affectionately revealed God.

- Vital impetus (Élan vital) of Henri Bergson (1907).

- apetitus (Spinoza).

- unmeasured passion (S. Kierkegaard).

- existential famine / void (retributive relation: waged [6]), that is made up by "sovereign Word" that thereafter is "cultivated" by "psychoanalytic Word". This cause psychoanalytically brings us around to adoption of opinion about the procedure of recall from man (cf. infant) a previous situation of beatitude; that is to say man seeks a pre-Fallen "Eden" (pre-symbolic Real) where did not exist neither biological, neither mental, neither existential, neither metaphysical "hunger" and "thirst". The objective of an eternally 
unsatisfied wish (that is to say alienable one) -because of Original Sin, according to Christian Theology- is indelible and this of course refers in the primitive division of the subject (cf. the meaning of jouissance of J. Lacan). By this we mean that always there is the relationship between a significant and a signifiant (cf. split subject). However it is this precisely the impossibility of satisfaction that keeps live the wish: "We do not receive never what to we had promised but consequently we do not stop never to long for it'[7]. In other words, infant based on previous experiences of satisfaction that have been registered as mnemonic traces in the systems of perception, seeks to re-invest the mnemonic picture of this perception and to recall it, namely to restore the situation of the first satisfaction[8].

- $\quad$ being sorely pricked and Dependence (Fr. Schleiermacher).

- Divine Neume (see Numen): knock/call; we mean the attraction that Mystery practices in man (R. Otto).

- Divine Eros (Plato, Basil the Great, Attachment theory[9]): affectionately relationship (son).

b. because of existence metaphysical or spiritual (religious) cerebral torus (recipient) or specific centre (see Neuro-theology), and

c. because of the pursuit of existential meaning (of life): "Seek me that you may live" (Amos).

All these multiple reasons of an approach of "Absolute being" declare that the universal (pan-anthropic) turn for "Divine" (Absolute) neither springs from a primitive fear, neither happens one catholic psychopath. The human nature $(<\operatorname{Imago} D e i>)$, even if wounded, seeks for its fulfillment to be linked to the source of its origin. On the other side that is to say from the viewpoint of acquired, this inclination of man can be intensified, cultivated, or be slacked, if it is being repressed.

\section{Philosophical viewpoint the "Absolute Being" in Philosophy}

From the ancient until modern Philosophy generally "absolute being" is considered explicitly or implicitly- either as autonomous (entity) or as some provider of various values:

a) Transcendent or (either metaphysical or uncreated) God,

b)agnostically (Protagoras), that is to say it is not given to "Absolute being" particular gravity and rather it wanted to be ignored,

c) naturalistically (cf. pre-Socratic philosophers) as Nature or Fate / Destiny (cf. Necessity),

d) the Whole (see Holism),

e) an (national, social, political, religious etc.) Ideology,

f) present (see Presentism),

g)past (see Traditionalism),

h) future (cf. Futurism / Eschatology),

i) law (cf. "symbolic father", according to Lacanian Psychoanalysis),

j) enjoyment (see Hedonism),

k)imaginary or material idols (persons, things, sports etc),

1) Society (K. Marx),

m) closed community or communities (Ch. Yiannaras),

n) fellow-man ("neighbour"),

o)zero / Null (nothing): Nihilism (J.-P. Sartre),

p)chaos (see lawlessness / Antinomianism: anarchy),

q) love (Eros), 
r) war / violence - discord (Heraclitus; cf. Discordianism) or "becoming" (see Existentialism),

s) collective self-institution (Politic),

t) Economy (cf. Homo economicus),

u) egoistically (J. Fichte), namely Ego itself is highlighted and is premised (see selfreferentially),

v) as the (unreachable) "thing by itself" (I. Kant),

w) as something extra-world (K. Gödel, L. Wittgenstein, K. Jaspers),

$\mathrm{x}$ )as an internal "substance" (cf. Phenomenology of E. Husserl),

y) as "esse" (Parmenides and M. Heidegger) and

z) as "material" (cf. pro-Socratic Hylozoism, Nietzsche, historical Materialism).

Ancient Greek Philosophy (mainly Plato and Aristotle) accepts the existence of Absolute or intellectually and abstractly (as the Ideas) or as the "First cause" (Aristotle).

Later, in the season of Sophists Absolute philosophical-theologically be jettisoned, e.g. with the Agnosticism of Protagoras, according to whom "Absolute" it is considered subjectively that the particular man considers each time as "absolute". But it is not logic and moral the atomistic desire to become and to function as a measure and criterion (canon) of everything because the atomistic desire is always ambiguous. Furthermore, if something of the kind preponderates in the difference between universality and specialness (or between universality and distinctness) will die out. In newer Philosophy, German philosopher Immanuel Kant (1724-1804) accepts as approachable only phenomena, while "thing by itself' as thoroughly inaccessible.

Then, according to German idealist theologian-philosopher Johann Fichte (1762-1814), as the Absolute is considered the human atomistic Ego, namely infinite position of our self via our self. In other words here the Divine "I AM THAT I AM" is shifted to human Ego that it consequently leads to Solipsism and Autism. Still, according to the Phenomenology (German Phänomenologie) of German philosopher and mathematician Edmund Husserl (1859-1938) [10], as Absolute it is considered the substance of things; we approach this "substance" by intuition (eidetic monitoring / eidetic image = grasp of the type or certain formalities) in conformity with an intentionality or relating (cf. transcendental reduction). In this way, we receive an explicitness of all via the imaginary alterant.

Moreover, Austrian-British philosopher Ludwig Wittgenstein (1889-1951) considers Absolute as current except of the world: "The meaning of world ", he writes, "should it is found outside by the world" [11](cf. theorem of Austrian-American mathematician and philosopher Kurt Friedrich Gödel). The same, mutatis mutandis, believed German psychiatrist and philosopher Karl Theodor Jaspers (1883-1969): "Philosophy streams from a level deeper than level of Philosophy" [12]! Finally, for German existential philosopher Martin Heidegger (1889-1976) as Absolute it is considered "esse" distinguishing -via the said "ontological difference"[13]- between "esse" and being. These various attitudes of Philosophy for Absolute express the distress of thinking human intellect for the seeking of a constant "foundation" in order to it supports any philosophical system, that is to say the meanings of the world and man. Simultaneously, however they show also the vainness, relativity, nihilism and disappointment of philosophizing Theo-logy without of Divine Revelation itself.

\section{A. Atheistic and/or materialistic Philosophy}

Philosophy diachronically may be divided -for methodological mainly reasons- into atheistic or materialistic and theistic. 
Atheistic (physiocratic / pagan and/or pantheistic) Philosophy, in general lines, may be sub-divided into:

a) Hylozoism,

b) Historical Materialism (Marxism),

c) Nietzscheanism with Dionysianism (Bacchism) [14] and "the death of God" (cf. Nihilism), and

d) the atheistic Existentialism mainly of French existentialist philosopher J.-P. Sartre (1905-1980), whereas "Absolute" is placed the ontological Nil.

Moreover, theistic Philosophy we can divide into secularistic (see Immanentism) and transcendental. Transcendental Philosophy can similarly be subdivided into "closed" (person-center / personalistic) and an "open" Theism.

I. Secularistic (Immanentismus).

\section{B. Theistic Philosophy}

Secularistic Philosophy (i.e. Immanentism) functions by necessity pantheistically. Indeed, Stoicism (cf. "Cosmic soul") and Gnosticism (cf. Cosmic panspermia) sustain as Absolute the "core" or the content of the universal world. Ancient Greek philosophers Xenophanes (570-480 B.C.) and Parmenides ( $6^{\text {th }}$ B.C. cent.) considered as Absolute the Word (cf. Logo-theism and Panlogism), something that will revive centuries later with the "reasonable Idea" or the "Absolute Spirit" of German philosopher Georg Hegel (17701831) via a pantheistic recycling. Similarly, for Dutch philosopher Baruch Spinoza (16321677) God and Nature (world) are identified. Moreover, German pessimist philosopher Arthur Schopenhauer (1788-1860) maintained world Will as Absolute. Similar philosophical systems "deified" the world as Panentheism (the world exists in God) and Theopanism (God is everything) of Irish Neo-Platonic theologian-philosopher Johannes Scotus Eriugena (810/5-877).

II. Transcendental.

We presume as Transcendental Philosophy the fiery Logos of Heraclitus. This Logos constituting from himself a paradox given that he joins opposite (cf. Unitas Multiplex) constitutes harmonious "coincidence of opposite" (Augustine, Nicolas Cusanus, Giordano Bruno). Then, as Transcendental Philosophy we consider the Platonic Idea ("world soul") of Good (cf. Idealism and Teleology of Plato).

Still, "the First cause" of Aristotle can be included in Transcendental Philosophy as the absolute perfection, i.e. "the intellect of intellect" or the pure intellect, in other words, the mental imago of God, that is to say mindological Theology (Aristotle, Aristotelianism, Thomism, Scholasticism). Similarly, Transcendental Philosophy consists in Plotinic Trinity (via of emanations), that is to say Enology (discourse about One).

Moreover, according to German philosopher Friedrich Schelling (1775-1854), God is considered as identification ideal and real, while he is incarnated in History with a lot of forms (cf. the heresy of Savellianism), coming out thus from himself and reentering "to the himself ".Finally, God as Absolute was identified by Saint Augustine with "summum bonum" (Johannes Hessen) or with the "value of values" (Max Scheler). More specifically, the Neo-Kantian Badische School considered God as the capitulation of values of true, beautiful and good. However, here we shall must observe that Absolute or God (uncreated generally) it is not possible to be identified with the human cultural values, since theologically it is not a man who set, designate, determine and judges Good and Values, but God. As it is obvious any Divine Revelation (cf. monotheistic religions) comes more nearer to a theistic Philosophy despite serious differences and reserves against to atheistic one. 


\section{C. "Closed" and "open" Theism.}

Theism is characterized "closed" because it is limited from the "personeidad" of Divine (cf. Augustine). In this (but inter- substantial) Theism belongs also Christian Religion on the one hand because of the Old Testamentical Imago Dei on the other hand of the New Testamentical Divine Incarnation. In this sense we speak about a god-man Philosophy (God as empiric and ultra-empiric, passive and apathetic, mundane and transcendental, created and uncreated), or a Theanthropism (cf. V. Solovyev, J. Popovits).

Thomas Aquinas (1225-1274) and more generally all the later Scholasticism in order to argue philosophically the cosmological evidence of existence of God, according to the apostle Paul, identified Aristotelian "cause of causes" with the personal God of Christianity. Similarly, Anselm of Canterbury (1033-1063) in order to compose the said ontological evidence of existence of God identified substance and existence into God. French philosopher and mathematician René Descartes (1596-1650) moved in the same vein arguing that since the human thought about the "absolute being" does not lie and sustain in a present finite world it should derive outside from this world (cf. Ch. Wolff).

And philosopher I. Kant albeit tried to avoid Theo-logy demolishing indeed all the scholastic proofs of the existence of God he could not finally avoid the said moral evidence of existence of God by right of the predicable imperative of practical reason.

Moreover both Deism and Dialectic Theology (K. Barth) belong with "closed" (person-center) Theism.

Then, as Affirmative (cf. ontological and teleological evidence, Onto-Theology etc.) as Negative Theology (God as not being, Null, that is to say as refusal of refusal, according to Pseudo-Dionysius Areopagita) talk of a personal God and a union of man with God. German-American theologian and Christian existentialist philosopher Paul Johannes Tillich (1886-1965) attempted to "ontologies" God (see Ontotheology), considering God as the "foundation of beings", as Bottom, Bottomless or Null (cf. Jakob Böhme, Nickolai Berdiayev). Nevertheless, a World-theism via analogia entis [15] that refers in Natural Theology and cosmological Theology, i.e. Eco-theology (that is to say Nature's of form divine) cannot orthodox Christianly become acceptable since an anyone (created) being, even absolute, cannot be identified with the creator of "esse" of beings.

Karl Jaspers is moved with a parallel way considering God as "Constrained" or "Holder together" (who contains the chief matter), that Christianly refers to the meaning of the Almighty (Greek Pantocrator), that is to say the One who keeps everything (universe).

\section{Theological viewpoint affirmative and negative Theology}

Firstly what theologically we name "Affirmative Theology" it isn't absolutely something single and concrete; nor, of course, in the Affirmative Theology God is identified with the Absolute or being, or even with both of them. Moreover, Orthodox Affirmative Theology is not identified with corresponding thomistic "via positivia" of approach of the Divine. What, in any case, generally appears that characterizes the considerate way of approach of Absolute or God in the Affirmative Theology is moving from bottom to up about the mode of doing theology as also and the reasonable-philosophical generally array and using of argumentation, insofar as (proportionally / analogically: "analogia entis") with scientific methodology (abduction, induction, reduction etc.) of the findings and conclusions of research. 
From the other side, the so-called "Negative Theology" has happened multiple interpretations and meanings up today -sometimes perfectly arbitrary- with the result an intensified conceptual confusion. From the beginning it will be said that Orthodox Negative Theology is not identified absolutely with corresponding (via negativa) Westerly one (Thomistic and Scholastic). Negative Theology of Orthodox Church is not neither Agnosticism, neither Scepticism, neither a theology of the so-called sociologically "empty types" (leerformel). On the contrary, it is a doxological Theology that does not "peer", according to the teaching of the Eastern Fathers particularly Saint John Chrysostom, the mystery but respectfully accepts it as "beyond reason". For this, many times Orthodox Negative Theology selects the silence before miracle instead of words. When however Negativism does theology it denies every created categorem and every quality in God. So for Negative Theology Christian God is not neither Absolute, neither, much more, being.

THE PERPETUAL APPROACH OF "ABSOLUTE BEING"

According to Christian Theology, anyone "approach" of the Absolute (as it is "mystery") appears basically a) perpetual, that is to say as an unceasing effort of man that it does not have end (cf. Orthodox Negative Theology)[16] and b) experiential psychosomatically.

Concretely, Saint Gregory of Nyssa writes: "the genuine enjoyment of desirable is continuously someone to get on in the searching of God and never does not stop to go up, because a wish that it is fulfilled, gives always birth another which is found above by this ... because the spirit having from this here the life a driver and an ally is ablaze into the love of God and the hot prayer of man who is burned by the Divine desire does not repletion but, as it is said, burned by the love of Good deriving thereby his soul always bigger eagerness; those who eat me they will hunger furthermore also those who drink me they will thirst furthermore (Syrah 24, 21)"'[17].

The perpetual this movement of God, which "quenches" the existential thirst of man does not come contrary to the Divine speech to a woman of Samaria that "Whosoever drinketh of the water that I shall give him shall never thirst" [18] or "Come unto me, all ye that labour and are heavy laden, and I will give you rest", because on the one hand the religiosity / spirituality of people lies in different levels on the other hand the life of Saints begins from earthly and transitory "perfection" [19] in order to it heads eternally to eschatological perfection[20]. In the beginning we have the first spiritual quenching of the spiritual infant with milk or chamomile. Later in the spiritual adultness of the faithful not only will quench with the cool water of Divine Grace but also self will be become a such spiritual fount [21] "insofar as the human ability" [22]. In between as long as more man approaches God so much he longs for Him! But this seeking is not agnostic (cf. altar ancient Greek "TO THE UNKNOWN GOD"), nor agonizing (coercive); it provokes more and more spiritual pleasure. Thus, Sober Fathers especially speak eschatologically for an "imperfect perfection", "because there is not end in the eternal goods".[23]

Also Professor Robert M. Torrance expresses itself proportionally: "The unfeasible of knowledge finally does not decrease our wish to acquire it; with the research we exceed at repetition present uncertainty in the frame of wider uncertainty that is always found beyond its bounds ... It is this search that it has made us, and continues making us, that is what we are".[24] Also American philosopher and mathematician, founder of American Pragmatism, Charles Sanders Peirce (1839-1914), observes: "facticity lies in the future"[25]. Finally, Austria-British philosopher Sir Karl Raimund Popper (1902-1994) remarks: "We are seekers of the truth and no its owners" [26]. 
Affirmative and Negative Theology confessedly endeavours to approach - everyone from its viewpoint - "Absolute being ", that is to say God. This effort, being human, remains relative and always dynamic. Orthodox (Affirmative and Negative) Theology believes that whoever human word about God does not correspond exactly with the truth, if previously God he has not also illuminates and hallows the thought and the language of theo-logian. In other words, no one Theology cannot be authentic, if it doesn't do according to meet for a god.

\section{Psychological viewpoint the "Absolute Being" in psychology}

In Psychology, in which various anthropological, philosophical, sociological and cultural opinions exert influence, as "absolute being" can be considered:

a) (conscious) Ego (Humanitarian, Existential and Positive Psychology),

b) unconscious - cf. unconscious God or Spirit (Eduard Hartmann),

c) the Superego (Über-Ich),

d) Ego Ideal (Ichideal),

c) Libido (Psychoanalysis of S. Freud),

d) complex superiority / supremacy (Alfred Adler),

e) will for force (Friedrich Nietzsche, Germanism),

f) Collective Unconscious (Carl Jung),

g) the force of will (Xenophon, Fathers of Church, Humanitarian Psychology),

h) "lack" and symbolic phallus / father (Jacques Lacan),

i) the initial world of soul (pre-symbolic Real) or mental unit (K. Castoriadis),

j) (natural and social) environment and Object relations theory [27]

k) dimension and prospect of future (Aaron T. Beck and Cognitive Psychology) and

1) "Spiritual" (Spirit) or Divine (Numen) or Sacred / Holy. [28]

Each psychological School by right of psychological Attribution theory, as "core" of human psychism, utmost reality and source each healthy or morbid behaviour, recognizes explicitly $\eta$ implicitly- a biological, mental, social, cultural, intellectual or spiritual and metaphysical principle.

An Orthodox answer in all these tendencies would be, according to the eclecticism of the Fathers of Church, the diacritical integration all of the operations or forces of psychosomatic existence of man given that depending on the character of each person and his environment when it can be in effect a principle and when the other. What, in any case, for is one more time confirmed here, is the inconceivable and the mystery of the human soul, as well as the endless its possibilities.

\section{Meanings of the approach of "Absolute Being"}

Any approach of "absolute being" can be comprehended generally:

a) Intellectualisticaly under the form either e.g. of Scholasticism, either of Isomorphism (there is a parallelism between the figural identity of the intuitive experience, namely of perception, and congruent neurophysiologic process or event of the brain). According to German historian, psychologist, sociologist and philosopher Wilhelm Dilthey (1833-1911) and the professor of Philosophy Michał Kazimierz Heller (1936-), for the one hand the natural phenomena it is in effect (descriptive) explanation, for the other hand the spiritual (hermeneutical) comprehension[29]

b) noetically (Platonism, philosophical Mysticism): opacity, penumbra, obscurity, darkness, dusk, gloom, quiet, incomprehension / acatalepsia (Plato, Origen, Clement 
of Alexandria, G. Basil, J. Chrysostom, Gregory of Nyssa, Ephraim Syros, Cyril of Jerusalem, John of Damascus), mystery, "docta ignorantia" (N. Cusanus), ineffable and innominate (anonymous) God, unrevealing (Deus absconditus); for this, for example, Christ spoke in parables, symbols, signs, marks, he kept his "Messianic secret" and he intended suitable moral and spiritual preparation and the progressive initiation, he accepted stages of receptivity, and he presupposed "from above" (Divine) light (as the awareness of nothingness, uncertainty, mystery, and of "one I Know that I Know nothing"). So, the alone way of approach of Divine - from the side of man - is divine doxology: by the view of light (deification) we were led to the revelation (disclosure) of word via word!

c) rationally / philosophically (Barlaam the Calabrian).

d) sentimentally (Naturalism, Romanticism, Schleiermacher, Mysticism).

e) volitionally (Sober Fathers).

f) God likely / doing synergistically Theology by to meet for a god (see apodictically / "halieutically"), according to Gregory of Palamas: as (diacritical) unity and no identity (as for energies and as for no the substance).

g) psycho-somatic / experiential “impletion" (filling up) - completeness / salvation [mysteries of the Church: penance / transfiguration (metamorphosis) in order to man keeps open house and see Invisible into Eucharist].

The above-mentioned multiple these meanings of "Absolute being" reveal the "openness" of man as regards in the searching and the approaching of "Absolute being", which Orthodox Church accepts since we Orthodoxically Christianly believe that during the union of man with God partake all of his psychosomatic forces.

PHILOSOPHICAL-RELIGIOUS WAYS OF APPROACH OF “ABSOLUTE BEING”

Up to today the known philosophical-religious ways of approach of "Absolute being" are:

a) via intellect / noesis (Plato),

b) via spread / unfold (Plotinus, Neo-Platonism) or trance / ecstasy (Philo),

c) via logic of Aristotle (see positive and analogical "way" of Thomas Aquinas,

d) via mystical intuition (see biological mysticism of $\mathrm{H}$. Bergson),

e) via logical "bound" [see absurd / paradox: "unquestioning faith" (Fideism) of S.

Kierkegaard and Luther],

f) via phenomenological intuition (Ed. Husserl),

g) via faith / confidence "according to knowledge" (see affectionate mutual respect) in an equivalent relation of Father - son or friend to friend (see Synergism).

RELIGIOUS-PSYCHOLOGICAL WAYS OF APPROACH OF “ABSOLUTE BEING"

Finally, also other hierographic ways of approach of "Absolute being" (Divine) exist (no however essentially "orthodox", but rather inclined towards Pantheism) as:

a) various metaphysical (or spiritual) experiences and reveals,

b) intimate affectionate with fellow being,

c) the necrosis of will (see Buddhist Nirvana, Schopenhauer),

d) Meditation,

e) various Mysticisms (see Quiet),

f) experiential empathy or/and identification,

g) caught up (see apostle Paul),

h) secular spirituality [union or/and (Buddhist) absorption from the Whole (Brahman, universal energy etc.)],

i) holistic Medicine (Medicine of personage and Integrative Psychology),

j) diacritical union / participation ("communion"): synergy Divine and human agent, 
Divine fear (anguish, swoon) and Divine love.

So much the various philosophical-theological what religious-psychological ways of approach of "Absolute being" that phenomenologically we described, testify the wealth and the dynamism of man in his effort of his "contact" with "Absolute" (Divine) but in the same time they contain also various mental, biological, moral, social and economic hazards if indiscriminately- they are generalized, intermingled and become absolute.

\section{CONCLUSIONS}

From the short this panoramic survey of the human penchant for the approach of "Absolute being" we saw that:

1. the expression "Absolute being" does not correspond in the teaching of Orthodox Christian Theology, but Philosophy and Philosophy of Religion.

2. man even if relative and closed-end (finite) has resources and ways -although deficient or imperfect- to express itself (doxologically, negatively etc.) for "Absolute".

3. the efforts (successful or unsuccessful) of man for the approach of "Absolute being" are diachronic, multidimensional and universal.

4. Philosophy cannot avoid the concept of "Absolute" regardless of for it is possible to be not this identified with a historical person but either with "being" or with existence.

5. the various philosophical definitions of "Absolute" confirm its vagueness and indetermination also the weakness of man.

6. any human word about God cannot be authentic, if it doesn't meet for a god.

7. because on the one hand during the union of man with God participate all psychosomatic forces of man on the other hand the essence of God remains completely inaccessible, as for the searching and the approach of God from the side of man functions, at least for Orthodox apperception, a liberality and "openness".

However, this wealth and the dynamism of a man making a bid for his "contact" with "Absolute" (Divine), contains various mental, biological, moral, social even economic or material hazards, if - without proper discernment of Holy Spirit - are not observed some "limits" that protect us against subjectivism, arbitrary interpretations, generalizations, improper medleys and absolutions.

\section{REFERENCES}

[1] See I. Kant, Kritik der reinen Vernunft, 1781, Kritik der praktischen Vernunft, 1788, Metaphysik der Sitten, 1797.

[2] Cf. Contra Eunomium, ed. W. Jaeger, Gregorii Nysseni opera, vols. 1.1 \& 2.2. Leiden: Brill, 1960: $1.1: 3-409 ; 2.2: 3-311$

[3] For the difference between searching and seeking out of God psychologically see S. K. Tsitsigkos, Religiosity, and desire - Religious-psychological study in the work of A. Vergote, ed. TREMENDUM, Athens 2010, pp. $121 \mathrm{f}$.

[4] Basil the Grate, Homiliae in Hexaemeron, MPG 29, 25.

[5] See G. Marcel, "Homo Viator”, 1962.

[6] Cf. John 10, 12-13.

[7] J. Stavrakakis, "The bounds of creation: social construction and political in Castoriadis and Lacan", in: Th. Lipovats - V. Romanos, Subject in postmodernism, ed. NESOS, Athens 2002, p. 109.

[8] S. Freud, Three Essays about the theory of Sexuality, gr. trans. by L. Anagnostou, ed. EPICURUS, Athens 1991, p. 105, J. Laplanche, Life and death in Psychoanalysis, London: The Johns Hopkins 
University Press, 1976, pp. 17, 58-62, 71, V. Romanos, "The meaning of autonomous subject after Kant”, in: Th. Lipovats - V. Romanos, Subject in postmodernism, ed. NESOS, Athens 2002, p. 29.

[9] See J. Bowlby, Attachment. Attachment and Loss, Vol. I. London: Hogarth, 1969, of the same, Attachment. Attachment and Loss, Vol. I (1982), New York: Basic Books, 19992.

[10] See E. Husserl, Logische Untersuchungen. Zweiter Teil: Untersuchungen zur Phänomenologie und Theorie der Erkenntnis (Logical Investigations, Vol 2), 1901, Cf. Tractatus Logico-Philosophicus, 6.4, C. K. Ogden (trans.), London: Routledge \& Kegan Paul, Originally published as "LogischPhilosophische Abhandlung", in: Annalen der Naturphilosophische, XIV (1921-1922) 3/4.

[11] Cf. Philosophie, Berlin: Springer, trans. by E. B. Ashton, Chicago: Chicago University Press, 1969-1971.

[12] Cf. L. M. Vail, Heidegger and Ontological Difference, The Pennsylvania State University Press, University Park and London, 1972.

[13] Cf. O. Clément, Theology after "the death of God", Athens 1973.

[14] Cf. E. Przywara, Analogia entis, Johannes - Verlag, 1962.

[15] On this subject about the unceasing effort of scientific research generally see Ch. Peirce, Collected Papers of Charles Sanders Peirce, 8 volumes, 1931-58, edited (1-6) by Charles Hartshorne and Paul Weiss and (7-8) by Arthur Burks, K. Popper, Of Clouds and Clocks, in Objective Knowledge: An Evolutionary Approach, Oxford 1972, R. M. Torrance, The spiritual quest: Transcendence in myth, religion and science, Berkeley, CA: University of California Press, 1994.

[16] In Canticum canticorum (homiliae 15), ed. H. Langerbeck, Gregorii Nysseni opera, vol. 6. Leiden: Brill, 1960: 3-469.

[17] John 4, 14.

[18] Matth. 11, 28.

[19] Philip. 3, 12, A' Kop. 13, 10-12: "But when that which is perfect is come, then that which is in part shall be done away. When I was a child, I spoke as a child, I understood as a child, I thought as a child: but when I became a man, I put away childish things. For now we see through a glass, darkly; but then face to face: now I know in part; but then shall I know even as also I am known".

[20] John 4, 14. 7, 38.

[21] Callistos \& Ignatius Xanthopouloi, "About those who choose to live quietly", LOVE FOR THE BEAUTIFUL (Philokalia) OF HOLY SOBERS, lxxxvii, Athens 1976, vol. IV, p. 281.

[22] Op. cit.

[23] See R. M. Torrance, The spiritual quest: Transcendence in myth, religion and science, Berkeley, CA: University of California Press, 1994.

[24] Collected Papers of Charles Sanders Peirce, 8 volumes, 1931-58, edited (1-6) by Charles Hartshorne and Paul Weiss and (7-8) by Arthur Burks.

[25] Of Clouds and Clocks, in: Objective Knowledge: An Evolutionary Approach, Oxford 1972.

[26] See W. R. D. Fairbairn, An Object-Relations Theory of the Personality, New York: Basic Books, 1952, L. Gomez, An Introduction to Object Relations Theory, London: Free Association Press, 1997.

[27] E. Spranger, Lebensformen; Halle (Saale): Niemeyer, 1914, E. Durkheim, Germany Above All , 1915, R. Otto, The Idea of the Holy (1917), Oxford University Press, USA, 19582, M. Eliade, The sacred and the profane - The nature of religion (1957), San Diego: Harvest/HBJ, Trask, W. R. trans. 1987, K. Pargament, Spiritually Integrated Psychotherapy: Understanding and Addressing the Sacred, Guilford Press, New York, 2007.

[28] The move from understanding to explaining meant a drop down "below" the mental level and into the biological and physical realms of brain and behavior (see L. Sass, Madness and Modernism, Cambridge: Harvard University Press, 1992). Cf. C. A. Anderson, M. R. Lepper \& L. Ross, "Perseverance of social theories: The role of explanation in the persistence of discredited information", Journal of Personality \& Social Psychology 39 (1980) 1037- 49. 